"Determinants of the credit risk in developing countries: a case of Kosovo banking sector"

\begin{tabular}{|c|c|c|}
\hline \multirow{2}{*}{$\begin{array}{l}\text { AUTHORS } \\
\text { ARTICLE INFO }\end{array}$} & \multicolumn{2}{|l|}{$\begin{array}{l}\text { Jehona Shkodra } \\
\text { Hysen Ismajli }\end{array}$} \\
\hline & \multicolumn{2}{|c|}{$\begin{array}{l}\text { Jehona Shkodra and Hysen Ismajli (2017). Determinants of the credit risk in } \\
\text { developing countries: a case of Kosovo banking sector. Banks and Bank } \\
\text { Systems, 12(4), 90-97. doi:10.21511/bbs.12(4).2017.08 }\end{array}$} \\
\hline DOI & \multicolumn{2}{|c|}{ http://dx.doi.org/10.21511/bbs.12(4).2017.08 } \\
\hline RELEASED ON & \multicolumn{2}{|l|}{ Thursday, 30 November 2017} \\
\hline RECEIVED ON & \multicolumn{2}{|l|}{ Sunday, 05 February 2017} \\
\hline ACCEPTED ON & \multicolumn{2}{|l|}{ Wednesday, 11 October 2017} \\
\hline LICENSE & \multicolumn{2}{|c|}{$\begin{array}{l}\text { This work is licensed under a Creative Commons Attribution-NonCommercial } 4.0 \\
\text { International License }\end{array}$} \\
\hline JOURNAL & \multicolumn{2}{|l|}{ "Banks and Bank Systems" } \\
\hline ISSN PRINT & \multicolumn{2}{|l|}{$1816-7403$} \\
\hline ISSN ONLINE & \multicolumn{2}{|l|}{$1991-7074$} \\
\hline PUBLISHER & \multicolumn{2}{|c|}{ LLC "Consulting Publishing Company "Business Perspectives" } \\
\hline FOUNDER & \multicolumn{2}{|c|}{ LLC "Consulting Publishing Company "Business Perspectives" } \\
\hline $0^{\infty}$ & 15 & $\begin{array}{l}\text { ニここ } \\
\Xi \Xi Z\end{array}$ \\
\hline NUMBER OF REFERENCES & NUMBER OF FIGURES & NUMBER OF TABLES \\
\hline 22 & 1 & 5 \\
\hline
\end{tabular}

(c) The author(s) 2022. This publication is an open access article. 


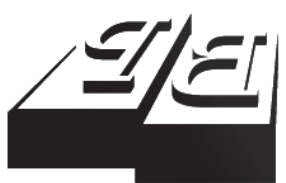

BUSINESS PERSPECTIVES

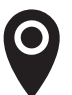

LLC "CPC "Business Perspectives" Hryhorii Skovoroda lane, 10, Sumy, 40022, Ukraine

www.businessperspectives.org

Received on: $5^{\text {th }}$ of February, 2017 Accepted on: $11^{\text {th }}$ of October, 2017

(C) Jehona Shkodra,

Hysen Ismajli, 2017

Jehona Shkodra, Assistant Professor of Finance, Banking, Accounting, University of Prishtina "Hasan Prishtina", Kosovo.

Hysen Ismajli, Associate Professor of Finance, Banking, Accounting, University of Prishtina "Hasan Prishtina”, Kosovo.

\section{DETERMINANTS OF THE CREDIT RISK IN DEVELOPING COUNTRIES: A CASE OF KOSOVO BANKING SECTOR}

\begin{abstract}
The determinant of the credit risk of banks in a developing country have limited data to analyze and limited participation in literature. Determinants of credit risk are very important in order to define the non-performing loans (NPL) in Kosovo banking systems. Even though banking system in Kosovo is the newest in region, it is comparable with banking systems to all places in regions (Albania, Serbia, Montenegro, Macedonia, Bosnia and Herzegovina, etc.).

The main purpose of this paper is to classify some factors that influence credit risk in commercial banks in Kosovo. The research includes seven commercial banks for the period 2006-2015. Data analysis and interpretation are processed with Statistical Program for Social Sciences SPSS v.19.0.

The effect of variations in the determinants of credit risk exposure is based on using a multivariate panel regression model. Our empirical results suggest that a significant relationship exists between credit risk and the following variables: Profitability (ROE and ROA), Inefficiency (IE), Loans to deposit ratio (LDR), Credit growth (CG) and Deposit rate (DR), while variables of Solvency (SR) and Credit rate (CR) are not statistically significant in terms of credit risk.
\end{abstract}

Keywords Kosovo, determinants, commercial banking, credit risk

\section{JEL Classification C3, E43, E5, F33, G3}

\section{INTRODUCTION}

Financial markets play a key role in facilitating risk sharing and efficient allocation of assets among investors (Chabakauri \& Han, 2016). Financial sector in Kosovo is under supervision of Kosovo Central Bank (KCB), which supervises financial system in compliance to current law competences. Actually there are ten banks that operate in Kosovo where eight of them operate with foreign capital including 93.1\% of overall banking sector capital and two other banks operate with native capital including $6.9 \%$ of overall banking sector capital (KCB, 2015). Credit giving activity from commercial banks continues to represent one of the main sources of commercial banks (Shkodra et al., 2012). Credits play a very important role for countries in transition such as Kosovo in creating, increasing and developing business activities (Shkodra et al., 2011).

Financial sector is categorized as a very important pillar for economic stability and in Kosovo this sector compared to other places in the region is very stable (Shkodra et al., 2012). The last financial crisis and recession have made non-performing loans one of the major concerns for both bank managers and regulatory authorities. The recent financial crisis has called the attention to the consequences that banking crises 
Table 1. Banking risk matrix

Source: KCB 2015

\begin{tabular}{|c|c|c|c|c|}
\hline \multicolumn{5}{|c|}{ BANKING RISK PROFILE } \\
\hline RISK CATEGORY & $\begin{array}{l}\text { Risk management } \\
\text { quantity } \\
\text { (low, medium, high) }\end{array}$ & $\begin{array}{c}\text { Risk management } \\
\text { quality } \\
\text { (week, acceptable, } \\
\text { strong) }\end{array}$ & $\begin{array}{c}\text { General } \\
\text { risk level } \\
\text { (low, medium, high) }\end{array}$ & $\begin{array}{c}\text { Risk direction } \\
\text { (increasing } \uparrow, \\
\text { stable } \leftrightarrow, \\
\text { decreasing } \downarrow \text { ) }\end{array}$ \\
\hline GENERAL RISK & $\mathrm{HIGH}$ & WEAK & $\mathrm{HIGH}$ & INCREASING \\
\hline $\begin{array}{l}\text { LOAN } \\
\text { - juristic persons } \\
\text { borrowing } \\
\text { - individual borrowing } \\
\text { - commercial borrowing } \\
\text { - real estate } \\
\text { - small and medium } \\
\text { entrepreneurship }\end{array}$ & $\mathrm{HIGH}$ & WEAK & $\mathrm{HIGH}$ & INCREASING \\
\hline $\begin{array}{l}\text { MARKET } \\
\text { deposits and decision } \\
\text { making }\end{array}$ & MEDIUM & WEAK & MEDIUM & INCREASING \\
\hline $\begin{array}{l}\text { LIQUIDITY } \\
\text { - treasure and investments } \\
\text { - trade } \\
\text { - derivatives } \\
\text { - swaps } \\
\text { - international } \\
\text { - deposits and investment } \\
\text { decision making }\end{array}$ & MEDIUM & WEAK & MEDIUM & INCREASING \\
\hline $\begin{array}{l}\text { OPERACIONAL } \\
\text { - individual } \\
\text { - operations } \\
\text { - operations for } \\
\text { - juridical persons } \\
\text { - system and processes } \\
\text { - politics and procedures } \\
\text { - human recourses } \\
\text { - income system } \\
\text { - information system } \\
\text { - services of internal and } \\
\text { - external auditing }\end{array}$ & $\mathrm{HIGH}$ & WEAK & $\mathrm{HIGH}$ & INCREASING \\
\hline PLACE/TRANSFERS & MEDIUM & ACCEPTABLE & MEDIUM & STABLE \\
\hline
\end{tabular}

can have on the economy (Agnello \& Sousa, 2011). For this reason, some economists look again at the factors that may trigger a banking crisis (De Grauwe, 2010; Laeven \& Valencia, 2010). Bank credit risk in emerging markets showing causal relationship between economic growth, real interest rate, the net interest margins, the real exchange rate appreciation, and non-performing loans is analyzed by Fofack (2005).

The risk is a process that needs to be identified and managed with a continuous and dynamic precisely accuracy in every financial institution while including all risks spectrum such as: a) credit risk, b) market risk, c) liquidity risk, d) operational risk, and e) transferred risk ${ }^{1}$. Credit risk management is one of the most serious challenges of financial sector which is influenced mostly by both internal factor and external factors which should not be neglected. KCB which supervises financial institutions in Kosovo uses risks matrix (see Table 1) in order to collect the levels of risks of a particular financial institution activity (KCB, Financial Supervisor Manual, 2015).

In order to assess and to identify identical and comprehensive risks in all banks and then to apply in compliance with current laws and rules the KCB has determined assessment systems CAMELS and CAELS as a general frame for monitoring risks.

Assessment system CAMELS involves: assessment of capital sufficiency, credit risk and financial means quality, management, gains, liquidity risk, sensitivity from trade risk, operational risk, internal checks, internal auditing, compliance with $\mathrm{KCB}$ recommendations and focused examination during month.

1 Risk, which may come from other countries, because 8 banks with foreign capital operate in Kosovo. 
Assessment system CAELS involves: general risk, credit risk, liquidity risk, sensitivity from trade risk and operational risk.

Based on the fact that debts include the major group of banking activities and are major source of gain for each bank as well, we consider that credit risk has an important influence and requires a special concentration. Credit risk management is a systematic issue which requires special attention from each institution that deals with credit giving.

Based on probability categorization of credit risk - a) low; b) medium; and c) high - in Kosovo credit risk is assessed to be high, whereas according to the way categorization of credit risk - a) decreasing; b) stable; and c) increasing - credit risk is assessed to be increasing.

Because banking industry is considered as a sensitive industry taking into account the fact that it faces high and different risks KCB should take a special consideration when creating rules and laws to keep financial system stable which may influence the economy of Kosovo. According to KCB (KCB, Clients debt in banks in Kosovo, 2015) overload of debts in banks apart from direct risk to financial sector stability involves also social and psychological influence of debtors and society in general.

KCB has undertaken a series of measures to keep financial stability of the country and to protect from unperformed credits of commercial banks such as: a) obligated reserves measure - where every bank is obligated to deposit means in KCB and to use them when credit converge became impossible; b) credit provision measure - where every bank is obligated to pay provision to KCB for each credit issued; c) liquidity measure - where every bank is obligated to keep the level of liquidity determined by KCB in order to cover obligation toward client in every time.

Weak credit risk management will cause the increase in unperformed credits which can lead to financial instability or, according to Cooper et al. (2003), variations in credit risks would lead to variations in the health of banks' loan portfolio which in turn affects bank performance. Gonzalez-Hermosillo et al. (1997) define the higher share of NPLs to total loans leads to the greater probability of banking failure. The level of NPL and provisions in commercial banks in Kosovo are represented in Figure 1.

Figure 1 shows that NPL to total credit ratio has been increased each year from 2008 to 2013; in 2008 NPL included 3.3\% of overall credits in banking system in Kosovo, whereas in 2015 NPL reached 6.2\%, so the NPL in 2014 started decreasing trend. From Table 2 we see that Kosovo has a very good performance in comparison to the countries in the region.

Source: BQK reports, 2009-2016.

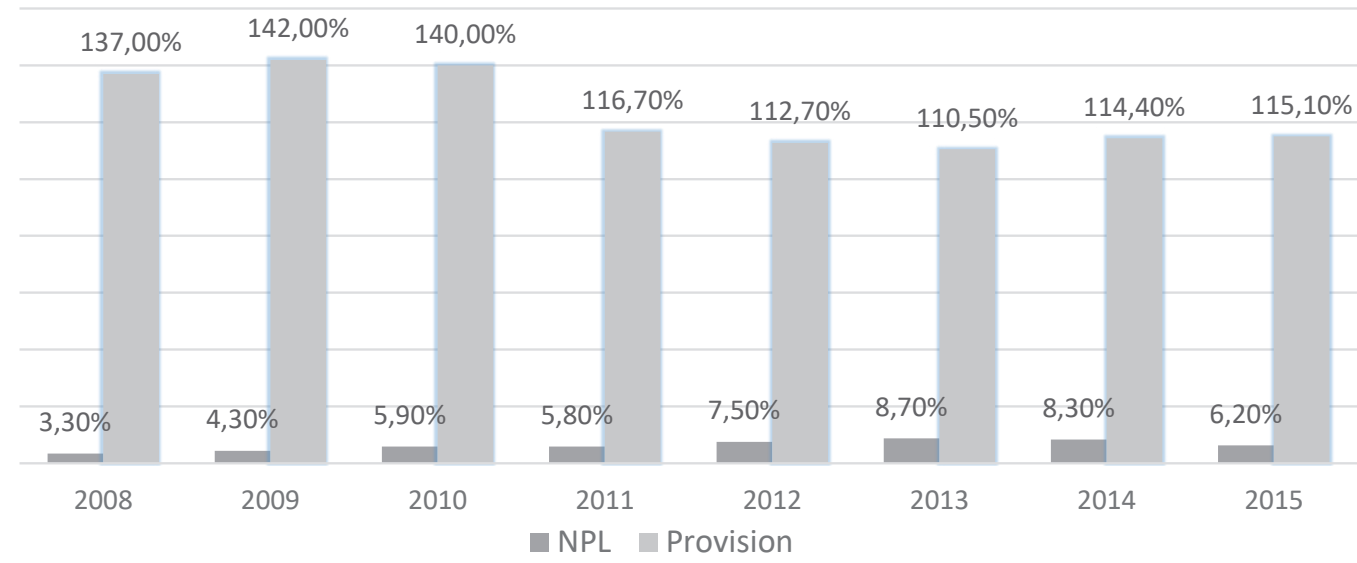

Figure 1. NPL and provisions for the period of 2008-2015 
Table 2. NPL in reports of total gross credits

Sours: World bank (IBRD-IDA), 2016

\begin{tabular}{|c|c|c|c|c|c|c|c|c|c|}
\hline Place & 2008 & 2009 & 2010 & 2011 & 2012 & 2013 & 2014 & 2015 & 2016 \\
\hline Kosovo & $3.30 \%$ & $4.30 \%$ & $5.80 \%$ & $5.70 \%$ & $7.40 \%$ & $8.50 \%$ & $8.30 \%$ & $6.20 \%$ & $6.20 \%$ \\
\hline Albania & $6.60 \%$ & $10.50 \%$ & $14.00 \%$ & $18.80 \%$ & $22.50 \%$ & $23.50 \%$ & $22.80 \%$ & $18.20 \%$ & $20.00 \%$ \\
\hline Macedonia & $6.70 \%$ & $8.90 \%$ & $9.00 \%$ & $9.50 \%$ & $10.10 \%$ & $10.90 \%$ & $10.80 \%$ & $10.30 \%$ & $7.20 \%$ \\
\hline Montenegro & $7.20 \%$ & $13.50 \%$ & $21.00 \%$ & $15.50 \%$ & $17.60 \%$ & $18.40 \%$ & $16.80 \%$ & $13.40 \%$ & - \\
\hline Serbia & $11.30 \%$ & $15.70 \%$ & $16.90 \%$ & $20.00 \%$ & $18.60 \%$ & $21.40 \%$ & $21.54 \%$ & $21.60 \%$ & $21.00 \%$ \\
\hline
\end{tabular}

\section{ANALYSIS OF CREDIT RISK} DETERMINANTS

The data are taken from publication reports, but in some cases we need to calculate average data because the data hasn't been checked. To calculate determinants in credit risk we analyze: Profitability (ROE and ROA), Inefficiency (IE), Loans to deposit ratio $(L D R)$, Credit growth $(C G)$, Deposit rate $(D R)$, Solvency $(S R)$ and Credit rate $(c r)$.

The model of multivariate regression is as follows:

$C R_{i t}=f\left(\begin{array}{l}R O A, R O E, I E, \\ L T D, C G, D R, S R, c r\end{array}\right)$,

(1) Now we will see calculations done for assessment of selected variables which will not significantly impact credit risk and those which have impact on

$C R_{i t}=\beta_{0}+\beta_{1} \cdot R O A_{i t}+\beta_{2} \cdot R O E_{i t}+$

$+\beta_{3} \cdot I E_{i t}+\beta_{4} \cdot L D R_{i t}+\beta_{5} \cdot C G_{i t}+$ credit risk.

where $\beta_{0}, \beta_{1}, \beta_{2}, \beta_{3}, \beta_{4}, \beta_{5}, \beta_{6}, \beta_{7}$ and $\beta_{8}$ are parameters (coefficients).

Dependent variable is Credit Risk (CR) as the share of non-performing loans on total volume of loans for bank $i$ in year $t-C R_{i t}, i=7$ banks; $t=10$ yea; $\varepsilon_{i t}=$ error.

H0 - Hypothesis: Which variables have no significant impact on credit risk of commercial banks in Kosovo? $+\beta_{6} \cdot D R_{i t}+\beta_{7} \cdot S R_{i t}+\beta_{8} \cdot R C_{i t}+\ldots+\varepsilon_{i t}$,

Table 3. Correlation matrix of bank specific variables

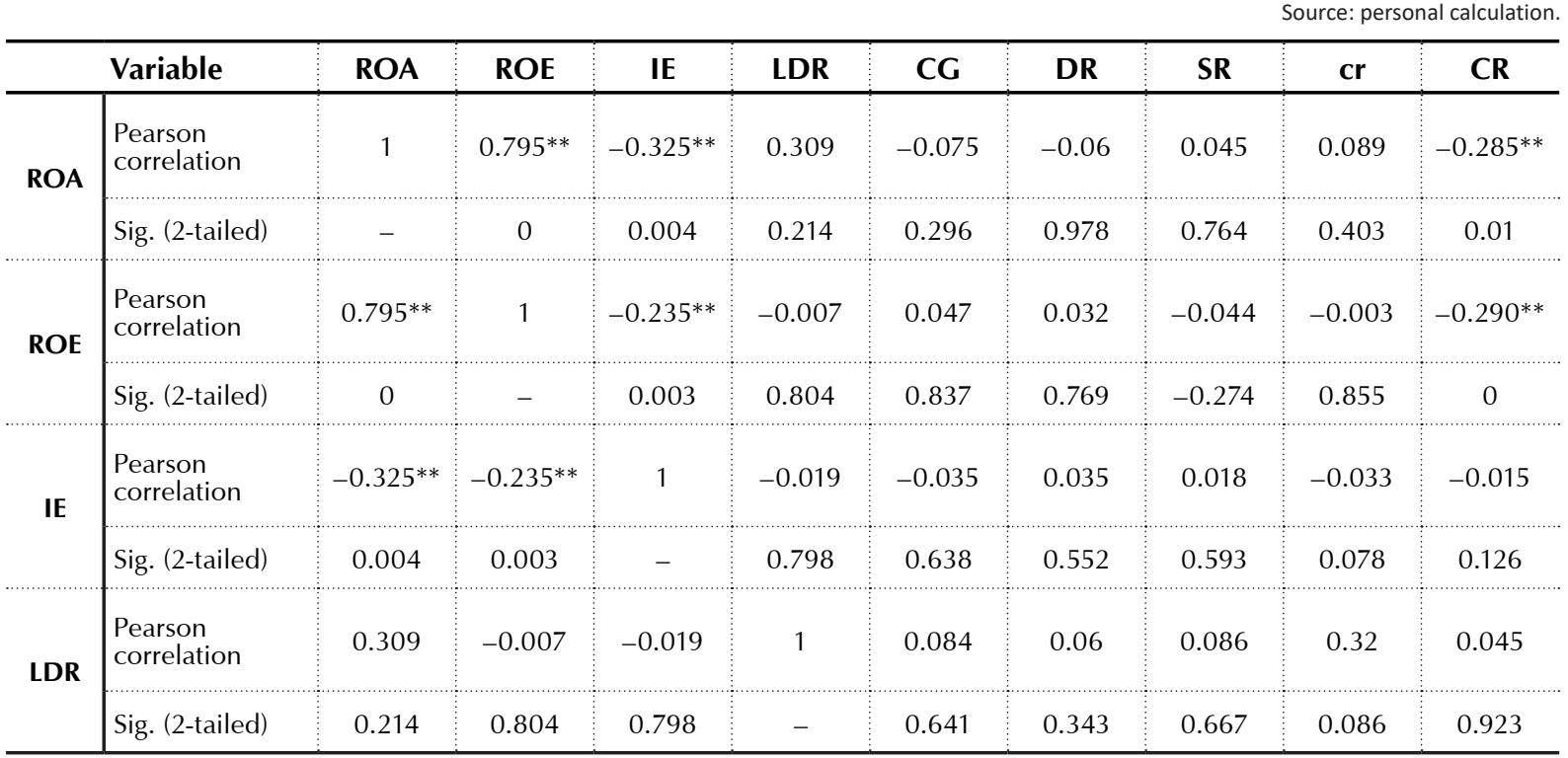


Table 3 (cont.). Correlation matrix of bank specific variables

\begin{tabular}{|c|c|c|c|c|c|c|c|c|c|c|}
\hline & Variable & ROA & ROE & IE & LDR & CG & DR & SR & $\mathbf{C r}$ & CR \\
\hline \multirow[t]{2}{*}{ CG } & $\begin{array}{l}\text { Pearson } \\
\text { correlation }\end{array}$ & -0.075 & 0.047 & -0.035 & 0.084 & 1 & 0.04 & $0.156^{*}$ & 0.119 & $-0.102^{* *}$ \\
\hline & Sig. (2-tailed) & 0.296 & 0.837 & 0.638 & 0.641 & - & 0.824 & 0.057 & 0.13 & 0.002 \\
\hline \multirow[t]{2}{*}{ DR } & $\begin{array}{l}\text { Pearson } \\
\text { correlation }\end{array}$ & -0.06 & 0.032 & 0.035 & 0.06 & 0.04 & 1 & -0.003 & -0.004 & 0.213 \\
\hline & Sig. (2-tailed) & 0.978 & 0.769 & 0.552 & 0.343 & 0.824 & -- & 0.828 & 0.873 & 0.212 \\
\hline \multirow[t]{2}{*}{ SR } & $\begin{array}{l}\text { Pearson } \\
\text { correlation }\end{array}$ & 0.045 & -0.044 & 0.018 & 0.086 & $0.156^{*}$ & -0.003 & 1 & $0.482^{* *}$ & 0.088 \\
\hline & Sig. (2-tailed) & 0.764 & -0.274 & 0.593 & 0.667 & 0.057 & 0.828 & - & 0 & 0.703 \\
\hline \multirow[t]{2}{*}{$\mathrm{Cr}$} & $\begin{array}{l}\text { Pearson } \\
\text { correlation }\end{array}$ & 0.089 & -0.003 & -0.033 & 0.32 & 0.119 & -0.004 & $0.482^{* *}$ & 1 & -0.002 \\
\hline & Sig. (2-tailed) & 0.403 & 0.855 & 0.078 & 0.086 & 0.13 & 0.873 & 0 & - & 0.961 \\
\hline \multirow[t]{2}{*}{ CR } & $\begin{array}{l}\text { Pearson } \\
\text { correlation }\end{array}$ & $-0.285^{* *}$ & $-0.290^{* *}$ & -0.015 & 0.045 & $-0.102^{* *}$ & 0.213 & 0.088 & -0.002 & 1 \\
\hline & Sig. (2-tailed) & 0.01 & 0 & 0.126 & 0.923 & 0.002 & 0.212 & 0.703 & 0.961 & - \\
\hline
\end{tabular}

Note: ${ }^{\star}$ Correlation is significant at the 0.05 level. ${ }^{*}$ Correlation is significant at the 0.01 level.

Table 4. Common effect model

Source: personal calculation.

\begin{tabular}{|c|c|c|c|c|c|c|c|}
\hline \multirow{2}{*}{$\begin{array}{c}\text { Model } \\
\text { Variable }\end{array}$} & \multicolumn{2}{|c|}{$\begin{array}{c}\text { Non-standardized } \\
\text { coefficients }\end{array}$} & \multirow{2}{*}{$\begin{array}{c}\begin{array}{c}\text { Standardized } \\
\text { coefficients }\end{array} \\
\text { Beta }\end{array}$} & \multirow[t]{2}{*}{$\mathbf{T}$} & \multirow{2}{*}{ Sig. } & \multirow[t]{2}{*}{ Tolerance } & \multirow[t]{2}{*}{ VIF } \\
\hline & B & Std. error & & & & & \\
\hline$C$ & 0.03424 & 0.08 & - & 3.044 & 0 & & \\
\hline $\mathrm{ROA}$ & -0.11410 & 0.189 & -0.01 & -0.685 & 0.494 & 0.558 & 1.869 \\
\hline ROE & 0.11422 & 0.026 & 0.41 & 2.252 & 0 & 0.537 & 1.853 \\
\hline IE & -0.00421 & 0.003 & -0.089 & -1.323 & 0.004 & 0.814 & 1.071 \\
\hline LDR & 0.00212 & 0.044 & 0.035 & 0.242 & 0.313 & 0.844 & 1.070 \\
\hline CG & -0.01203 & 0.005 & -0.111 & -1.314 & 0 & 0.832 & 1.09 \\
\hline DR & 0.03132 & 0.028 & 0.147 & 1.012 & 0.020 & 0.838 & 1.099 \\
\hline SR & 0.03919 & 0.04 & 0.15 & 1.37 & 0.104 & 0.67 & 1.682 \\
\hline $\mathrm{Cr}$ & -0.00031 & 0.011 & -0.06 & -0.103 & 0.45 & 0.78 & 1.527 \\
\hline
\end{tabular}

Table 5. Model summary

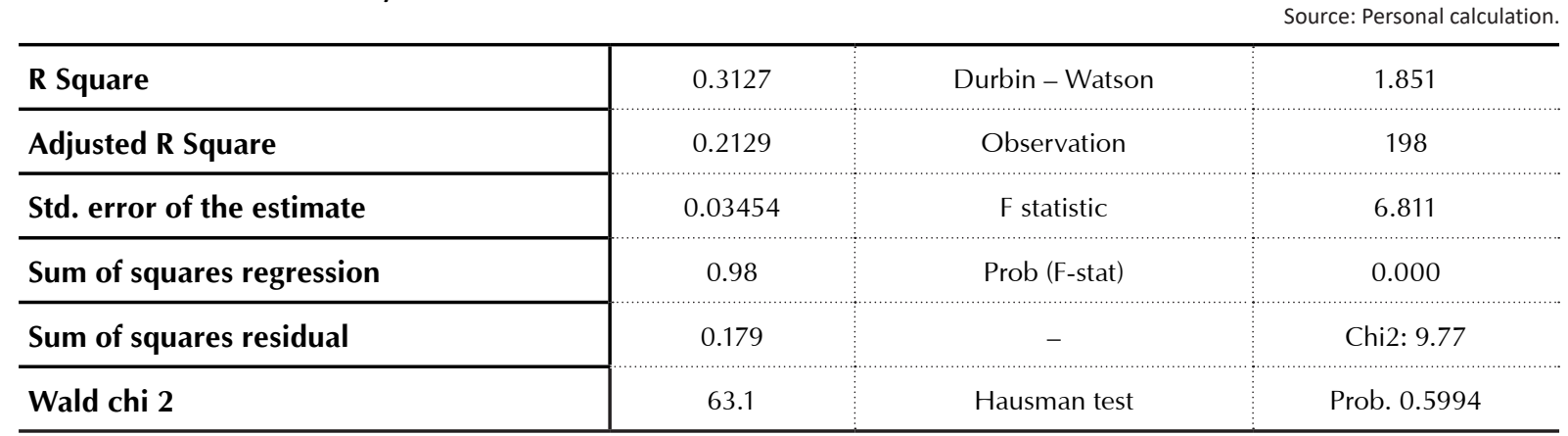




\section{RESULT INTERPRETATION}

Table 3 presents correlation analysis for all variables including dependent and independent variables. To determine parametric or nonparametric test the Kolmogorov - Smirnov goodness of fit test is used.

The coefficients of Pearson correlation in Table 3 show a positive correlation what is important, but we find not significant correlation between $L D R$ (Loans deposit rate) and $C R$ (credit risk), between $S R$ (solvency) and $C R$ (credit risk), as well as between the $D R$ (deposit rate) and the $C R$ (credit risk). The opposite of that is a negative correlation, which we show at the Pearson correlation coefficients relation between $\mathrm{cr}$ (credit rate) and $C R$ (credit risk).

Table 4 showed also the problem of multicollinearity by using the VIF (variance inflation factor). There is no serious problem with the use of our model of the multicollinearity, because all VIF values are identified less than 2 (the highest VIF has value of 1.869).

This holds that the presence of multicollinearity is minimal. In order to examine the heteroscedasticity problem in the model, Durbin - Watson (DW) test was used. While examining the heteroscedasticity in Table 5, one may note that the observed positive autocorrelation is 1.851 for credit risk. Endogeneity in the model was tested by Hausman test. The Hausman test based on Chi-squared statistic (9.77, and prob. 0.5994 ) indicates that corresponding effects are statistically insignificant, so the null hypothesis is accepted and random effect model is preferred.

The Hausman test simultaneously examines the justification for the use of instrumental variables as possible solutions to the endogeneity problem.

In terms of the significance of all the independent variables taken together the F-test was used with significance of 5\%. It implies that our model is a good fit because in Table 4 it can be seen the F statistic (6.811) of the probability for the overall regression relationship is $<0.005$. It can be concluded that we reject the null hypothesis that all coefficients are simultaneously zero and accept that the overall regression is significant.

Furthermore, individual t-tests show that four variables in our Model (IE, ROE, CG and DR) are found to be statistically significant at the empirical significance level of less than 5\%. Linear combination of explanatory variables formed the regression function in our model that provides R-squared coefficient of determination of $31.27 \%$. The regression results are given in Table 4. The R-Squared statistic indicates that all these 8 predictor variables combined explain $31.27 \%$ of the variance in credit risk. The remaining nearly $68.73 \%$ of the variations in Credit risk can be explained by factors that are not included in our model. The standard error of the estimate shows the standard deviation of the residuals to be .03454 . The adjusted R-squared statistic, which is more suitable for comparing models with different numbers of independent variables, is $21.29 \%$. When assessing the impact of independent variables on credit risk variable $R O E$ has the most influence whose regression standardized coefficient by a variable ROE (beta is 0.41 ), followed by a variable $C G$ (beta is -0.111 ) and variable $D R$ (0.147). As it can be observed from the summary of regression output, all other regression coefficients were not statistically significant because the p-value is larger than 0.05 . Besides, the regression results also revealed that only four variables have significant impact on the model. The characteristic variables in our model are ROA $(-0.11410), I E$ $(-0.00421), C G(-0.01203)$ and $c r(-0.00031)$ which have reciprocal relationship with the $C R$. It means that when each of these variables increases, it leads to lower $C R$. On the other side of the coin, positive relationships with $C R$ have the following variables: $R O E$ (0.11422), $L D R$ (0.00212), $D R(0.03132)$ and $S R$ $(0.03919)$ which means that when each of these variables decreases, it leads to raise $C R$.

\section{CONCLUSIONS}

Following on from the results we found out that a significant relationship exists between credit risk and the following variables: Profitability (ROE and $R O A)$; Inefficiency (IE); Loans to deposit ratio (LDR); Credit growth $(C G)$ and Deposit rate $(D R)$, while variables Solvency $(S R)$ and Credit rate $(c r)$ are not statistically significant in terms of credit risk $(C R)$. 
The findings of this study showed that banking credit risk is significantly negatively affected by $I E$ and $C G$. It means that with the growth of credit risk the banks' cost efficiency and lending of the banks decline. Moreover, the negative statistically significant value of $I E$ and $C G$ suggests that the both variables have a substantial impact on credit risk. Further, a negative coefficient of IE (0.00421) implies that increase in efficiency leads to decrease in credit risk as well as with $C G(0.01203)$.

Coefficient of 0.03132 , which has $D R$ shows that any increase in this variable leads to increase in $C R$. The value of 0.11422 is a positive coefficient of $R O E$ which means that increase in $R O E$ leads to $C R$. Moreover, the results of the study demonstrate that $R O A, L D R$ and $c r$ coefficients estimate is positive, however, statistically not significant. The low coefficient of $L D R 0.00212$ suggests that $L D R$ has weak impact on the CR.

The relationship between the $R O E$ and $C R$ is positive and also significant. Lastly, $R O A$ and $S R$ also don't have any significant relationship with $C R$. In conformity of econometric methods in this research we can confirm the hypothesis in the case of Kosovo that the highest importance in explaining the variability of credit risk in banks is inherent to the following variables: Profitability $(R O E)$, Inefficiency (IE), Credit growth $(C G)$ and Deposit rate $(D R)$ while variables Profitability $(R O A)$, Loans to deposit ratio $(L D R)$, Solvency $(S R)$ and credit rate $(c r)$ are not statistically significant in terms of credit risk.

\section{REFERENCE}

1. Agnello, L., \& Sousa, R. (2011). How do Banking Crises Impact on Income Inequality NIPE Working Papers WP 30/2011. University of Minho. http://dx.doi.org/10.1080/1 3504851.2011 .631885

2. Autoriteti Kosovar i Konkurrencës (2011). Analiza e Monitorimit të Konkurrencës në Sektorin Bankar në Kosovë.

3. Castro, V. (2013). Macroeconomic determinants of the credit risk in the banking system: The case of the GIPSI. Economic Modelling, 31, 672-683. http:// dx.doi.org/10.1016/j.econmod.2013.01.027

4. Central Bank of Republic of Kosovo. Annual Report: 2015, 2014, 2013, 2012, 2011, 2010, 2009, 2008, 2007, 2006, 2005, 2004.

5. Cooper, M. J., Jackson, W. E., \& Patterson, G. A. (2003). Evidence of predictability in the crosssection of bank stock returns. Journal of Banking \& Finance, 27(5), 817-850. http://dx.doi:10.1016/ S0378-4266(01)00263-1

6. De Grauwe, Paul (2010). The banking crisis: causes, consequences and remedies. Palgrave Macmillan UK.

7. Fofack, H. (2005). Nonperforming loans in Sub-Saharan Africa: causal analysis and macroeconomic implications. World Bank Policy Research Working Paper, (3769). Retrieved from http://hdl.handle. net/10986/8498

8. Garr, D. K. (2013). Determinants of Credit Risk in the Banking Industry of Ghana. Developing Country Studies, 3(11), 64-77.

9. Georgy Chabakauri, Brandon Yueyang Han (2016). Capital Requirements and Asset Prices. Retrieved from http://ssrn.com/ abstract $=2689672$

10. González-Hermosillo, B., Pazarbaşioğlu, C., \& Billings, R. (1997). Determinants of banking system fragility: a case study of Mexico. Staff Papers-International Monetary Fund, 295-314. https:// doi.org/10.2307/3867561

11. Govori, F. (2013). The performance of commercial banks and the determinants of profitability: Evidence from Kosovo. MPRA Paper No, 46824, 1-13. Retrieved from http://mpra.ub.uni-muenchen. de/46824/

12. Jehona Shkodra, Hysen Ismaili, Drini Salko \& Visar Beqiri (2012). Credit risk management in commercial banks in Kosovo. International Journal of Business and Management Studies, 1(3),
115-124. Retrieved from https:// www.researchgate.net/publication/297704273

13. Klein, N. (2013). Non-performing loans in CESEE: Determinants and impact on macroeconomic performance. Retrieved from https://ssrn.com/abstract=2247224

14. Laeven, L., Valencia, F. (2010). Resolution of Banking Crises: The Good, the Bad, and the Ugly. IMF Working Paper 10/146

15. Musyoki, D. (2011). The Impact of Credit Risk Management on the Financial Performance of Commercial Banks in Kenya. Journal of Business and Public Management, 2(2), 72-80. http:// dx.doi:10.9790/5933-0704017283

16. Mwaurah, I. G. (2013). The Determinants of credit risk in commercial banks in Kenya (Doctoral dissertation, University of Nairobi). Retrieved from http:// erepository.uonbi.ac.ke:8080/xmlui/ handle/123456789/59685

17. Nabila Zribi \& Younes Boujelbène (2011). The factors influencing bank credit risk: The case of Tunisia. Journal of Accounting and Taxation, 3(4), 70-78.

18. Nkusu, M. (2011). Nonperforming loans and macrofinancial 
vulnerabilities in advanced economies. IMF Working Papers, 1-27. http://dx.doi:10.5897/ JAT11.006

19. Pestova, A., \& Mamonov, M. (2013). Macroeconomic and bankspecific determinants of credit risk: Evidence from Russia (No. 13/10e). EERC Research Network, Russia and CIS. Retrieved from https://EconPapers.repec.org/Re PEc:beo:journl:v:62:y:2017:i:212 :p:155-188

20. Petrit Balija (2014). Overview of the financial sector in Kosovo. Kosovo banking associations.
21. Shkodra JEHONA, Salko DRINI, \& Gjergjizi HALIM (2011).

Agricultural credits in development of small farms in Kosovo. http://doi. org/10.13140/RG.2.1.2020.0085

22. Wold bank (IBRID-IDA) (2016). Retrieved from http://data.worldbank.org/indicator/FB.AST.NPER. ZS?locations 